\section{The Role of Family Character in Cooperation Agreements}

\author{
Cristina López-Cózar-Navarro' ${ }^{1}$ \\ ${ }^{1}$ Polytechnic University of Madrid, Agrarian Economics, \\ Statistics and Business Management, Madrid, Spain
}

Tiziana Priede-Bergamini ${ }^{2}$

${ }^{2}$ European University of Madrid, Economy and Business, Madrid, Spain

\section{Sonia Benito-Hernández ${ }^{1}$}

\section{Abstract}

Purpose - This paper aims to study the differences between family and non-family firms when establishing cooperation agreements.

Design/methodology/approach - The empirical research was conducted using a sample of 1,848 firms, of which 828 are family firms. The use of statistical regression estimation is based on the binary logistic model.

Findings - The results show important differences between family and non-family firms in relation to interfirm cooperation and the innovation capacity of the firms, their quality concerns, and their ability to develop external relationships.

Originality/value - This paper contributes to the literature by offering new insights in relation to cooperation strategies in family firms, analyzing the effect on the different types of cooperation due to the diverse nature of the chosen partner, as well as the effect of certain internal capabilities of the firm.

Keywords - Inter-firm cooperation; family firms; partner.
Recebimento:

03/12/2019

Aprovaçáo:

12/03/2019

Editor responsável:

Prof. Dr. Leire San-Jose

Avaliado pelo sistema:

Double Blind Review 


\section{Introduction}

Business cooperation is a widely discussed topic in the literature; however, few studies have focused on the specific case of the family businesses (FBs) and, moreover, there is no clear consensus on the relationship between cooperation and family character (Niemelä, 2004; Roessl, 2005; Pittino \& Visintin, 2011; Classen, Van Gils, Bammens, \& Carree, 2012; Franco \& Haase, 2012; Pittino, Visintin, Bau', \& Mazzurana, 2013; Alberti, Ferrario, Papa, \& Pizzurno, 2014; Feranita, Kotlar, \& De Massis, 2017). Given the importance of FBs around the world, and because their peculiarities make their strategic behavior different from that of other companies (BenitoHernández, Priede-Bergamini, \& López-CózarNavarro, 2014; De Massis, Frattini, Pizzurno, \& Cassia, 2015; Padilla-Meléndez, Dieguez-Soto, \& Garrido-Moreno, 2015), it seems relevant to develop an analysis in this research line (Feranita et al., 2017; Brinkerink, 2018).

This paper aims to study the differences between family and non-family firms when establishing cooperation agreements. Indeed, the desire of FBs to maintain control of their activities and their conservative nature can determine the scope of such agreements. Hence, the study intends to examine this issue in more depth and complete the literature by empirically analyzing the relationship with different aspects of the company, such as the innovation capacity, the quality management, and the ability to manage external relationships, emphasizing the case of FBs. Following previous research (Hoang \& Rothaermel, 2005; Fink \& Kessler, 2010; Zeng, Xieb, \& Tam, 2010), we consider that these are three determining factors when developing cooperation agreements.

It is therefore proposed to consider whether FBs with a greater capacity for innovation, that are more concerned with quality management, and that have a greater interest in improving external relations, develop cooperation. In addition, the literature shows that there are important differences between cooperation agreements depending on the nature of the relationship between the partners, so that it is possible to distinguish between vertical cooperation (agreements with suppliers and customers), horizontal cooperation (agreements with competitors), and institutional cooperation (agreements with universities and technology centers). Nevertheless, except for some papers like those of Classen et al. (2012), Alberti et al. (2014), López-Cózar-Navarro, Benito-Hernández, and Platero-Jaime (2017), and Feranita et al. (2017), there has so far been limited research in the FB literature on the diversity of partners in inter-firm cooperation. Consequently, we include the analysis of each type of cooperation to contribute to the research regarding this topic.

Specifically, this paper has two main objectives: (1) to analyze if family firms with more innovation capacity and that are more involved in quality and continuous improvement in their relations with external partners develop interfirm cooperation; and (2) to analyze if there is a relationship between inter-firm cooperation and the family character depending on the type of cooperation (chosen partner). To achieve the goals, an empirical study is developed based on the data obtained in the Survey on Business Strategies (SBSS) of 1,848 companies, of which 828 are family firms. The paper is structured as follows. First, the working assumptions are presented, linking business cooperation in FBs to the chosen variables. The working methodology and results obtained are then described. Finally, the main conclusions derived from the investigation are presented.

\section{Literature review and hypothesis formulation}

For many years, cooperation strategies have been very widely used in corporate activities like research and development, the commercialization of products, and obtaining different supplies. At the same time, the importance of inter-firm cooperation in the business field has also drawn 
academic attention, promoting a large number of studies and publications on the topic.

Previous empirical and theoretical papers have identified the different factors that justify intern-firm cooperation. In general terms, it has many advantages for firms as it facilitates access to resources, allows risk sharing, and provides cost advantages (Das \& Teng, 2000; Miotti \& Sachwald, 2003; Belderbos, Carree, Diederen, \& Lokshin, 2004; Chun \& Mun, 2012). Similarly, several studies show that cooperation increases the competitiveness and performance of companies (Das \& Teng, 2000; Chung \& Kim, 2003; Surroca \& Santamaría, 2007).

In addition, the literature shows that there are important differences between cooperation agreements depending on the nature of the relationship between the partners (Tether, 2002; Cassiman \& Veugelers, 2002; Belderbos et al., 2004; Nieto \& Santamaría, 2007; Surroca \& Santamaría, 2007). Customer feedback can be invaluable in the innovation process, especially in defining the attributes and characteristics of products (Tether, 2002; Surroca \& Santamaría, 2007). It also facilitates access to new markets and helps the company identify new business opportunities (Hagedoorn, 1993). Meanwhile, cooperation with suppliers is mainly intended to reduce costs and to improve the design of new products (Chung \& Kim, 2003; Belderbos et al., 2004; Surroca \& Santamaría 2007).

Agreements with current or potential competitors can facilitate access to complementary resources and exploit economies of scale, although it can also increase the risk of unintentional knowledge leakage (Cassiman \& Veugelers, 2002; Miotti \& Sachwald, 2003; Olander, HurmelinnaLaukkanen, \& Mähönen, 2009). Consequently, this type of cooperation is often used with projects that do not contain key information of the companies involved (Tether, 2002). This is information that could be considered confidential, which the company does not wish to share with third parties, such as the description of a manufacturing method or a prototype.
Institutional cooperation refers to relationships with universities and research institutes. These organizations have traditionally been a source of new knowledge, but in recent years, they have been subject to governmental pressure to get closer to companies, by conducting research that contributes to further improving their competitiveness (Surroca \& Santamaría, 2007). The importance of this type of cooperation has been cited in the literature, especially in the manufacturing sector (Serrano-Bedia, López-Fernández, \& García-Piqueres, 2010). Additionally, Jones and Corral de Zubielqui (2017) find a positive relationship between cooperation with universities, the capacity for innovation, and the company's results.

\section{I Inter-firm cooperation and family character}

While business cooperation is widely dealt with in literature, its relationship with family character has been much less studied (Franco \& Haase, 2012; Feranita et al., 2017; Brinkerink, 2018). Some authors show that certain characteristics of FBs may favor the development of cooperation agreements with third parties. For example, family objectives and needs, as well as their long-term orientation, are often decisive factors for managers and affect decision-making. Zahra, Hayton, and Salvato (2004) found that the organizational culture of a FB, based on beliefs and family values, has considerable strategic relevance. The commitment and loyalty of the people participating in the organization, as well as the knowledge, skills, motivation, and power of the family entrepreneur, have a positive influence in fostering cooperative relationships (Niemelä, 2004; Roessl, 2005). On many occasions, factors that tend to promote cooperation between companies are often cultural rather than economic in nature (Härtel, Bozer \& Levin, 2009), thus the trust and loyalty that comes with a FB is an important advantage when establishing these type of agreements (Franco \& Haase, 2012). 
It should be noted, however, that the specific characteristics of FBs may also impede such cooperation. So, risk aversion, the conservative behavior of these companies, the lack of professionalization, and the specific culture, which may not be understood by their partners and cause a lack of communication between the parties, may hinder cooperation (Roessl, 2005). Pittino and Visintin (2011) suggest that FBs are less likely to reach agreements than non-family ones. In their work on the various forms of entry into new markets, Pongelli, Caroli, and Cucculelli (2016) show that the desire of FBs to maintain a long-term orientation and family control makes them prefer not to make agreements with external partners; however, they also point out that the presence of non-family members moderates this preference. Brinkerink (2018) points out that the fact that a FB does not want to lose control of its activities may be an obstacle when establishing cooperation agreements.

In light of the various results presented, it appears that the peculiarities presented by FBs when making decisions on whether to establish cooperation agreements with third parties may be different from those of other companies. Consequently, the following hypothesis is proposed:

$\mathbf{H}_{1}$ - There is a positive relationship between business cooperation and the family character of the firm.

\subsection{Inter-firm cooperation and innovation}

Many studies have analyzed the relationship between inter-firm cooperation and innovative results (Santamaría \& Surroca 2011), frequently finding a positive relationship between them (Miotti \& Sachwald, 2003; Rogers, 2004; Faems, Van Looy, \& Debackere, 2005; Hoang \& Rothaermel, 2005; Nieto \& Santamaría, 2007; Zeng et al., 2010; Santamaría \& Surroca, 2011).

Likewise, numerous studies have analyzed the role of innovation in FBs (Zahra, 2005; Naldi et al., 2007; De Massis, Frattini, \& Lichtenthaler, 2012a; De Massis, Sharma, Chua, \& Chrisman, 2012b; Kellermanns, Eddleston, Sarathy, \& Murphy, 2012; Weismeier-Sammer, 2014; Duran, Kammerlander, Van Essen, \& Zellweger, 2016) and several studies show that there are differences between FBs and non-family ones in terms of innovation activity (Chrisman \& Patel, 2012; Classen, Carree, Van Gils, \& Peters, 2014; De Massis et al., 2015; Diéguez-Soto, Manzaneque, \& Rojo-Ramírez, 2016; Werner, Schröder, \& Chlosta, 2018). Understanding the complex relationships between the family and the company is essential when analyzing decisions and results. However, despite being an interesting question due to the peculiarities that these types of companies present, as pointed out by De Massis et al. (2015) and Padilla-Meléndez et al. (2015), it is still not a dominant topic in the literature. It is therefore appropriate to further study how family character influences the innovative behavior of FBs (Chrisman, Chua, De Massis, Minola, \& Vismara, 2016; Sanchez-Famoso, Maseda, \& Iturralde, 2017).

Moreover, FB behavior also appears to be different from that of non-family businesses when establishing cooperation agreements (Nieto et al., 2015; Bigliardi \& Galati, 2018). Pittino et al. (2013) find that FBs are more likely than non-family ones to cooperate in technology exploration. Alberti et al. (2014) and Nieto et al. (2015) highlight the preference for internal resources instead of external collaboration, due to the possibility of losing relevant information during the process and complications when organizing the activity. In contrast, in a study on product innovation, De Masis et al. (2015) found that family firms tend to base their innovation activities on external sources of technologies and information. In this case, it seems that FBs tend to use a network of external collaborations to develop most of the phases of the innovation process. Broekaert, Andries, and Debackere (2016) show that FBs are more flexible than nonfamily ones, which favors cooperation agreements. Finally, in their work on cooperation to develop 
green solutions and the value of the resulting innovations, Ardito et al. (2019) found a positive relationship between FB participation and the development of innovations. In order to highlight this relationship, the following hypothesis is proposed:

$\mathbf{H}_{2}$ - There is a positive relationship between business cooperation strategies and FBs that develop innovation.

\subsection{Inter-firm cooperation and quality management}

The company's concern for quality management is also an important aspect to consider, as when business cooperation processes are developed, partners are committed to common continuous improvement and joint problemsolving (Soosay, Hyland, \& Ferrer, 2008). From a general perspective, quality management (also known as total quality management - TQM) allows the monitoring of all the activities that are necessary to maintain a desired level of excellence in the organization, which is articulated through the determination of a quality policy, its planning, guarantee, and control, as well as a joint commitment to continuous improvement. It is the adoption of a long-term management philosophy through the implementation of shortterm initiatives (Kaynak, 2003).

Hence, quality management is based on the principles of customer orientation, the continuous improvement of all internal processes, a people-based approach, and a global vision of the organization (Camisón, Boronat, Villar, \& Puig, 2009). So, commitment to proper quality management aims to increase the productivity of the organization, reduce costs, increase flexibility, increase employee motivation, improve reliability, etc. (Terziovski \& Sohal, 2000; Suárez-Barraza, 2013). In this line, the academic literature seems to confirm a positive relationship between the effective implementation of quality management and innovation (McAdam, Armstrong, \& Kelly, 1998; Tambunan, 2005; Martínez-Román,
Gamero, \& Tamayo, 2011; Tuffa Birru, 2011; Tamayo, Romero, Gamero, \& Martínez-Román, 2015), as well as with the company's results (Terziovski \& Sohal, 2000; Grütter, Field, \& Faull, 2002; Cho \& Pucik, 2005; Lakhal, Pasin, \& Limam, 2006).

Regarding FBs, Ellington, Jones, and Deane (1996) found that they are less likely to adopt quality management practices than nonfamily businesses; Cooper, Upton, and Seaman (2005) found no major differences between the two types of companies; whereas Danes, Loy, and Stafford (2008), Ibrahim, Angelidis, and Parsa, (2008), and Suárez-Barraza, RamisPujol, and Sándoval-Arzaga (2011) indicate that FBs are committed to quality management. Meanwhile, Garcés-Galdeano, García-Olaverri, García-Olaverri, Huerta, and Huerta (2016) show how those FBs that adopt these practices improve their results. However, the link between quality management and cooperation strategies in these companies has not yet been clarified; so, to improve the understanding of this relationship, the following hypothesis is proposed:

$\mathbf{H}_{3}-$ There is a positive relationship between cooperation strategies and FBs with quality control systems.

\subsection{Inter-firm cooperation and external relations}

Another important aspect of interfirm cooperation is establishing appropriate relationships with partners. As cooperation is based on trust between the alliance members, there must be a continuous flow of communication and information between them, allowing collaboration to evolve according to their needs (Fink \& Kessler, 2010).

According to the theory of social capital, the networks of collaborative relationships created between the members of a community constitute a very valuable resource in conducting the various projects between the parties and confer mutual recognition, respect, guarantees of rights, access to 
certain information, and opportunities (Nahapiet \& Ghoshal, 1998; Adler \& Kwon, 2002; SanchezFamoso, Akhter, Iturralde, Chirico, \& Maseda, 2015). This concept focuses on analyzing the type of relationships between the various members of a community and how these social contacts affect the very nature of those relationships (SanchezFamoso, 2015). Three relevant dimensions of social capital are identified: a structural one, involving the forms of connection between the parties; a relational dimension that captures the quality of the relationships based on trust and integrity; and a cognitive dimension, based on the common objectives of the members of the group and the extent to which they share those objectives (Nahapiet \& Ghoshal, 1998; SanchezFamoso et al., 2015).

As Sarkar, Echambadi, Cavusgil, and Aulakh (2001), Fernández and Martín (2006), and Larentis, Antonello, and Slongo (2018) show, the quality of the relationship between partners, based on trust and commitment, facilitates the establishment of long-term partnership agreements and is considered essential to the success of the cooperation.

With regard to the relationships between FBs and external partners, different authors have pointed out that $\mathrm{FBs}$ tend to relate with their environment in a special way to achieve stability and strength in their relationships with key external parties, achieving high levels of trust and commitment (Bingham, Dyer, Smith, \& Adams, 2011; Cabrera, Déniz, \& Martín, 2011), as the theory of social capital points out (SanchezFamoso, 2015). In this sense, the results obtained by Hadjielias and Poutziouris (2015) suggest that trust plays a key role in FB cooperation. Broekaert et al. (2016) indicate that to make business cooperation completely efficient, an appropriate organizational framework is needed to manage the relationships, and they show that FBs are able to manage external relations better than non-family businesses. Duran et al. (2016) argue that the special nature of FBs facilitates the development and maintenance of long-term, trust-based thirdparty relationships.

Therefore, to consider whether company mechanisms to improve relations with third parties promote cooperation, the following hypothesis is proposed:

$\mathbf{H}_{4}$ - There is a positive relationship between cooperation strategies and FBs that improve their relations with external parties.

\section{Methodology}

\section{I Sample and data source}

This study gathered data from the Survey on Business Strategies (SBSS) ${ }^{1}$. The SBSS is a statistical survey that collects data from an annual business survey sent to a panel of Spanish manufacturing companies regarding various aspects related to their strategic behavior and decision-making. The reference population of the SBSS are companies in the industrial sector with 10 or more employees. One of the most noteworthy features of the SBSS is its representativeness. The initial selection of companies was carried out by combining exhaustiveness and random sampling criteria. The geographical scope of reference is the whole of the Spanish territory and the variables have an annual time dimension. One of the common characteristics of the data set is that firms participating in the questionnaire are carefully chosen according to a selective sampling method. The SBSS database has already been used in previous FB studies (Surroca \& Santamaría, 2007; Benito-Hernández et al., 2014; Nieto et al., 2015; López-Cózar-Navarro et al., 2017; Mazzelli et al., 2018). Table 1 shows the technical data. 
Table 1

Technical data

\begin{tabular}{ll}
\hline Population & \\
\hline Unit & Spanish manufacturing sector \\
$\begin{array}{l}\text { Questionnaire design } \\
\text { Population types }\end{array}$ & SEPI Foundation \\
Time period & More than 100,000 elements \\
\hline Sampling & Data from 2012 \\
\hline Type of sampling & \\
& Random stratified census according to activity sector and firm size \\
Sample size & 1,848 Spanish manufacturing firms \\
Sampling error (approx.) & $0.028(\mathrm{p}=\mathrm{q}=0.50)$ \\
Level of confidence & $95 \%(\mathrm{~K}=2$ sigma) \\
Data treatment & Statistical Solutions for Products and Services (SPSS) \\
\hline
\end{tabular}

\subsection{Variables}

As a dependent variable, we work with business cooperation. Following Surroca and Santamaría (2007), Santamaría and Surroca (2011), and Nieto et al. (2015), we adopt a wide definition of cooperation, including a variety of agreements. This study will distinguish between vertical, horizontal, and institutional cooperation, depending on the chosen partner. The SBSS allows us to approach this analysis of cooperation by distinguishing between the different types of partners, since the survey contains a direct and dichotomous question (YES/NO) on whether the company has cooperated with clients (C_CLI), with suppliers (C_SUPP), with competitors (C_COM), and with universities or technology centers (C_UNI). In each case a dummy variable was created (a value of 1 indicates that the company has established cooperation agreements and the value 0 indicates that it has not). Previous studies have also formulated these variables as dichotomous (Tether, 2002; Chung \& Kim, 2003; Surroca \& Santamaría, 2007; Santamaría \& Surroca, 2011; De Marchi, 2012; Nieto et al., 2015; López-Cózar-Navarro et al., 2017; Werner et al., 2018).

\section{Independent variables:}

A wide variety of indicators have been used in the academic literature to measure family character (Werner et al., 2018). According to
De Massis et al. (2015) and Nieto et al. (2015), in FBs family members play a significant role in the ownership and in the management of the company, so decision-making power is in the hands of the owner family. This was included as a dichotomous variable (the value 1 indicates that the company is a FB and the value 0 indicates that it is not). This variable has been measured in many studies on different aspects related to FB management (Pittino et al., 2013; Classen et al., 2014; Benito-Hernádez et al., 2014; Nieto et al., 2015; Diéguez-Soto et al., 2016; López-CózarNavarro et al., 2017; Mazzelli et al., 2018).

Following Surroca and Santamaría (2007), we use two variables as an approximation of innovative results: process innovation (IPROC) if the company has been innovative in processes; and product innovation (IPROD) if the company has been innovative in products. In relation to quality (QUA), it is also included as a dichotomous variable (Martínez-Román et al., 2011; Tamayo et al., 2015), adopting the value 1 if the company performs standardization and quality control, and the value 0 otherwise. Finally, the external relationship variable is defined (RELAC). If the company introduces new organizational methods related to managing relationships with third parties, the variable adopts the value 1 , and 0 otherwise. In the literature we found studies that have used this variable measured in a dichotomous way (Broekaert et al., 2016). 


\section{Control variables:}

This work includes three control variables: geographical scope, size, and age of the company. Regarding the geographical scope of the company's activities (GEO), it is assumed that local businesses tend to cooperate more with agents in their near environment. Geographical proximity promotes trusting relationships and, consequently, cooperation between firms (Tuffa Birru, 2011).

The size (SIZE) and the age (AGE) of the company determine the initiatives carried out, since these variables generally represent the nature and amount of resources available (Benito-Hernández et al., 2014). Because smaller companies generally have fewer resources, they may seek cooperation to have access to the resources they lack. Following other studies on FBs, the variable size (SIZE) was measured by the logarithm of sales (Alberti et al., 2014; Classen et al., 2014) and the age variable (AGE) by the number of years since the firm's foundation (Benito-Hernández et al., 2014; Nieto et al., 2015). Table 2 provides a summary of the model variables.

Table 2

\section{Model variables}

\begin{tabular}{|c|c|c|c|c|}
\hline Variable type & Analyzed Variable & Definition & Name & Value \\
\hline \multirow[t]{8}{*}{ Dependent } & \multirow[t]{4}{*}{ Vertical Cooperation } & \multirow[t]{2}{*}{ Cooperates with suppliers } & \multirow[t]{2}{*}{ C_SUPP } & $1=$ yes \\
\hline & & & & $0=$ no \\
\hline & & \multirow[t]{2}{*}{ Cooperates with clients } & \multirow[t]{2}{*}{ C_CLI } & $1=$ yes \\
\hline & & & & $0=$ no \\
\hline & \multirow[t]{2}{*}{ Institutional Cooperation } & \multirow[t]{2}{*}{ Cooperates with universities } & \multirow[t]{2}{*}{ C_UNI } & $1=$ yes \\
\hline & & & & $0=$ no \\
\hline & \multirow[t]{2}{*}{ Horizontal Cooperation } & \multirow[t]{2}{*}{ Cooperates with competitors } & \multirow{2}{*}{ C_COM } & $1=$ yes \\
\hline & & & & $0=$ no \\
\hline \multirow[t]{8}{*}{ Independent } & \multirow[t]{2}{*}{ Quality } & \multirow{2}{*}{$\begin{array}{l}\text { Performs standardization and quality } \\
\text { control }\end{array}$} & \multirow[t]{2}{*}{ QUA } & $1=$ yes \\
\hline & & & & $0=$ no \\
\hline & \multirow[t]{2}{*}{ Family Character } & \multirow[t]{2}{*}{ The company is family-owned (FB) } & \multirow[t]{2}{*}{ FAM } & $1=$ yes \\
\hline & & & & $0=$ no \\
\hline & \multirow{2}{*}{$\begin{array}{l}\text { Innovation in external } \\
\text { relation management }\end{array}$} & \multirow{2}{*}{$\begin{array}{l}\text { Introduces new organizational } \\
\text { methods related to managing } \\
\text { relationships with third parties }\end{array}$} & \multirow[t]{2}{*}{ RELAC } & $1=$ yes \\
\hline & & & & $0=$ no \\
\hline & Process Innovation & $\begin{array}{l}\text { Introduces process improvements or } \\
\text { develops new processes }\end{array}$ & IPROC & $\begin{array}{l}\text { Number of process } \\
\text { innovations }\end{array}$ \\
\hline & Product Innovation & $\begin{array}{l}\text { Develops improvements to new } \\
\text { products }\end{array}$ & IPROD & $\begin{array}{l}\text { Number of product } \\
\text { innovations }\end{array}$ \\
\hline \multirow[t]{7}{*}{ Control } & Age & Age of the company & AGE & $\begin{array}{l}\text { Number of years } \\
\text { since foundation }\end{array}$ \\
\hline & \multirow[t]{5}{*}{ Geographical Scope } & \multirow{5}{*}{$\begin{array}{l}\text { Geographic scope of the main market } \\
\text { in which the company sells }\end{array}$} & \multirow[t]{5}{*}{ GEO } & $1=$ local \\
\hline & & & & $2=$ provincial \\
\hline & & & & $\begin{array}{l}3=\text { regional } \\
4=\text { national }\end{array}$ \\
\hline & & & & $\begin{array}{l}5=\text { international } \\
6=\text { internal and }\end{array}$ \\
\hline & & & & \\
\hline & Size & Company size & SIZE & Logarithm of sales \\
\hline
\end{tabular}

Source: author-compiled data. 


\subsection{Analysis methodology}

The model was tested with a sample composed of 1,848 Spanish companies in the manufacturing industry. Given the dichotomous nature of the dependent variable, binary logistic regression was used to assess the existence of dependency relationships between business cooperation and innovation, quality, and the improvement of external relations. A symmetric distribution (standard or logistical) and a maximum likelihood estimator were used, as in the binary logistic model. As the literature shows, there are other recent studies on FBs that have also used a binary logistic model (De Marchi, 2012; Pittino et al., 2013; Meroño-Cerdán \& López-Nicolás, 2017; López-Cózar-Navarro et al., 2017). Table 3 shows the models with their characteristics. Two types of analysis were developed: the first contains hypothesis $\mathrm{H}_{1}$ and the second includes hypotheses $\mathrm{H}_{2}, \mathrm{H}_{3}$, and $\mathrm{H}_{4}$.

Table 3

\section{Models}

\begin{tabular}{|c|c|c|c|c|c|}
\hline $\begin{array}{l}\text { General Model } \\
\left(C_{-} i_{i}\right)=\beta_{0}+\beta_{1} F A M_{i t}+ \\
\beta_{2} R E L A C_{i t}+\beta_{3} I P R O C_{i t}+ \\
\beta_{4} I P R O D_{i t}+\beta_{5} Q U A_{i t}+\beta_{6} G E O_{i t}+ \\
\beta_{A} A G E_{i t}+\beta_{8} S I Z E_{i t}+e_{i t}\end{array}$ & $\begin{array}{l}\text { Dep. } \\
\text { Variable } \\
\text { Cooperation with } \\
\ldots\end{array}$ & $\begin{array}{l}\text { Independent } \\
\text { Variables }\end{array}$ & $\begin{array}{c}\text { Control } \\
\text { Variables }\end{array}$ & Interactions & $\mathbf{H}_{\mathrm{i}}$ \\
\hline Model 1 & Suppliers & \multirow{8}{*}{$\begin{array}{c}\text { FAM, } \\
\text { RELAC, } \\
\text { IPROC, IPROD, } \\
\text { QUA }\end{array}$} & \multirow{8}{*}{$\begin{array}{l}\text { GEO, AGE, } \\
\text { SIZE }\end{array}$} & \multirow{8}{*}{$\begin{array}{l}\text { I_IPROC_FAM, } \\
\text { I_IPROD_FAM, } \\
\text { I_QUA_FAM, } \\
\text { I_RELAC_FAM }\end{array}$} & \multirow{4}{*}{$\mathrm{H}_{1}$} \\
\hline Model 2 & Customers & & & & \\
\hline Model 3 & Universities & & & & \\
\hline Model 4 & Competitors & & & & \\
\hline Model 5 & Suppliers & & & & \\
\hline Model 6 & Customers & & & & $\mathrm{H}_{2}$ \\
\hline Model 7 & Universities & & & & $\mathrm{H}_{4}$ \\
\hline Model 8 & Competitors & & & & \\
\hline
\end{tabular}

\subsection{Results}

The results of the descriptive statistics are given in Table 4. As can be seen, the sample is represented by mature companies with a medium size and mostly provincial/ national geographical scope. The most commonly used types of cooperation are those involving customers, competitors, and universities, with suppliers representing the least-used form of cooperation. Just under half of the companies that make up the sample are characterized as belonging to a family group.
Table 4

\section{Descriptive statistics}

\begin{tabular}{lcccc}
\hline \multicolumn{5}{c}{ Firms $(\mathbf{N}=\mathbf{1 , 8 4 8})$} \\
\hline Variables & Min & Max. & Mean & S.D \\
\hline C_SUPP & 0 & 1 & 0.21 & 0.40 \\
C_CLI & 0 & 1 & 0.16 & 0.36 \\
C_UNI & 0 & 1 & 0.24 & 0.42 \\
C_COM & 0 & 1 & 0.03 & 0.161 \\
FAM & 0 & 1 & 0.45 & 0.49 \\
RELAC & 0 & 1 & 0.89 & 0.30 \\
IPROC & 0 & 299 & 1.05 & 8.27 \\
IPROD & 0 & 50 & 1 & 4.14 \\
QUA & 0 & 1 & 0.45 & 0.49 \\
GEO & 1 & 6 & 4.24 & 1.42 \\
AGE & 1 & 5 & 4.11 & 1.13 \\
SIZE & 4.55 & 9.78 & 6.89 & 0.85 \\
\hline
\end{tabular}


Regarding frequencies, it was estimated that $44.8 \%$ of the sample companies are family ones and 39\% operate in Spain (GEO). It is also noted that the percentage of non-family enterprises operating at both the national and international levels is considerably higher than in the case of FBs, and that these are generally smaller and older. These results agree with the previous literature (Graves \& Thomas, 2008; Benito-Hernández et al., 2014; López-CózarNavarro et al., 2017).

Table 5 presents the correlations between the different variables.

Table 5

\section{Correlation matrix}

\begin{tabular}{|c|c|c|c|c|c|c|c|c|}
\hline & FAM & RELAC & IPROC & IPROD & QUA & GEO & AGE & SIZE \\
\hline FAM & 1.000 & & & & & & & \\
\hline RELAC & -0.013 & 1.000 & & & & & & \\
\hline IPROC & 0.038 & $-0.201\left(^{* *}\right)$ & 1.000 & & & & & \\
\hline IPROD & -0.099 & -0.057 & 0.035 & 1.000 & & & & \\
\hline QUA & 0.007 & $\left.-0.103{ }^{* *}\right)$ & $-0.186\left({ }^{* *}\right)$ & $-0.125\left(^{*}\right)$ & 1.000 & & & \\
\hline GEO & $-0.064\left(^{* *}\right)$ & $-0.056\left(^{*}\right)$ & $0.209\left(^{(* *}\right)$ & 0.085 & $-0.185\left(^{* *}\right)$ & 1.000 & & \\
\hline AGE & $0.088^{(* *)}$ & $-0.048\left({ }^{*}\right)$ & $0.097(* *)$ & $0.118\left(^{*}\right)$ & $-0.103\left({ }^{* *}\right)$ & $\left..01466^{(*)}\right)$ & 1.000 & \\
\hline SIZE & $-0.062\left(^{* *}\right)$ & $-0.164\left({ }^{* *}\right)$ & $0.260\left(^{(* *}\right)$ & $\left.0.258^{(* *}\right)$ & $\left.-0.331{ }^{* *}\right)$ & $0.450^{(* *)}$ & $\left.0.278^{(* *}\right)$ & 1.000 \\
\hline
\end{tabular}

For each pair of continuous variables, the Pearson's correlation coefficient is reported; otherwise the Spearman's correlation coefficient is given ${ }^{*} \mathrm{p}<0.05$; $^{* *} \mathrm{p}<0.01$.

As can be seen in Table 5, there is a significant negative correlation between family character (FAM) and size (SIZE), as well as with the extent of the firm's activities (GEO), and a positive relationship with the age variable (AGE). Concerning the other variables, a negative relationship was obtained between quality (QUA) and process innovation (IPROC), product innovation (IPROD), and external relationship improvement (RELAC). Similarly, there is a negative relationship between the geographical scope of the company's activities (GEO) and the improvement of external relations (RELAC), indicating that local companies are more likely to improve those relationships.

Tables 6 and 7 show the results of the different models proposed. Table 6 shows the results of the binary model that attempts to explain the various forms of cooperation through the four models (models 1-4), but does not include the interactions between variables, which are shown in Table 7 (models 5-8). 
Table 6

Binary Logistic Regression: Model results without interactions

\begin{tabular}{|c|c|c|c|c|c|c|}
\hline \multirow{5}{*}{$\begin{array}{l}\text { Modelo } \\
\text { General }\end{array}$} & \multicolumn{6}{|c|}{$\left(C_{-} i\right)=\beta_{0}+\beta_{1} F A M_{i}+\beta_{2} R E L A C_{i}+\beta_{3} I P R O C_{i}+\beta_{4} I P R O D_{i}+\beta_{5} Q U A_{i}+\beta_{6} G E O_{i}+\beta A G E_{i}+\beta_{8} S I Z E_{i}+\varepsilon_{i}$} \\
\hline & \multirow{4}{*}{$H_{\mathrm{i}}$} & & \multicolumn{4}{|c|}{1.848 firms } \\
\hline & & & Model $_{1}$ & Model $_{2}$ & Model $_{3}$ & Model $_{4}$ \\
\hline & & & C_SUPP $_{i}$ & $\mathrm{C}_{-} \mathrm{CLI}_{\mathrm{i}}$ & $\mathrm{C}_{-} \mathrm{UNI}_{\mathrm{i}}$ & $\mathrm{C}_{-} \mathrm{COM}_{\mathrm{i}}$ \\
\hline & & & $\begin{array}{l}\text { Coef. } \\
\text { (S.E) }\end{array}$ & $\begin{array}{l}\text { Coef. } \\
\text { (S.E) }\end{array}$ & $\begin{array}{l}\text { Coef. } \\
\text { (S.E) }\end{array}$ & $\begin{array}{l}\text { Coef. } \\
\text { (S.E) }\end{array}$ \\
\hline Const. & & & $\begin{array}{c}6.872^{* * *} \\
(2.037) \\
\end{array}$ & $\begin{array}{c}7.039^{* * *} \\
(2.141)\end{array}$ & $\begin{array}{c}.339^{* * *} \\
(1.968)\end{array}$ & $\begin{array}{c}12.253^{* * *} \\
(4.480) \\
\end{array}$ \\
\hline FAM & \multirow{3}{*}{$\mathbf{H}_{1}$} & & $\begin{array}{c}1.018^{* * *} \\
(0.346) \\
\end{array}$ & $\begin{array}{c}0.702^{* *} \\
(0.344) \\
\end{array}$ & $\begin{array}{c}0.088 \\
(0.313) \\
\end{array}$ & $\begin{array}{c}1.023 \\
(0.661) \\
\end{array}$ \\
\hline IPROC & & + & $\begin{array}{c}0.013 \\
(0.032) \\
\end{array}$ & $\begin{array}{c}-0.041 \\
(0.044) \\
\end{array}$ & $\begin{array}{c}0.045 \\
(0.032) \\
\end{array}$ & $\begin{array}{c}-0.270 \\
(0.215) \\
\end{array}$ \\
\hline IPROD & & + & $\begin{array}{c}0.007 \\
(0.037) \\
\end{array}$ & $\begin{array}{c}0.016 \\
(0.035)\end{array}$ & $\begin{array}{c}0.004 \\
(0.036) \\
\end{array}$ & $\begin{array}{c}0.115^{* *} \\
(0.039)\end{array}$ \\
\hline QUA & & + & $\begin{array}{c}1.182^{* * *} \\
(0.369)\end{array}$ & $\begin{array}{c}1.056^{* * *} \\
(0.392)\end{array}$ & $\begin{array}{c}0.114 \\
(0.322)\end{array}$ & $\begin{array}{l}2.134^{*} \\
(1.258)\end{array}$ \\
\hline RELAC & & + & $\begin{array}{c}-1.517^{* * *} \\
(0.436)\end{array}$ & $\begin{array}{l}-0.840^{*} \\
(0.430)\end{array}$ & $\begin{array}{c}-1.066^{* *} \\
(0.425)\end{array}$ & $\begin{array}{c}-1.185^{*} \\
(0.655)\end{array}$ \\
\hline GEO & & & $\begin{array}{c}-0.407^{* * *} \\
(0.145)\end{array}$ & $\begin{array}{c}0.521^{* * *} \\
(0.156)\end{array}$ & $\begin{array}{c}0.322^{* *} \\
(0.130)\end{array}$ & $\begin{array}{c}-0.190 \\
(0.296) \\
\end{array}$ \\
\hline AGE & & & $\begin{array}{c}-0.03 \\
(0.007) \\
\end{array}$ & $\begin{array}{c}0.011^{*} \\
(0.007) \\
\end{array}$ & $\begin{array}{c}0.004 \\
(0.006) \\
\end{array}$ & $\begin{array}{l}-0.006 \\
(0.012) \\
\end{array}$ \\
\hline SIZE & & & $\begin{array}{c}.053^{* * *} \\
(0.225) \\
\end{array}$ & $\begin{array}{c}0.701^{* * *} \\
(0.218)\end{array}$ & $\begin{array}{c}0.181^{* * *} \\
(0.210)\end{array}$ & $\begin{array}{c}1.657^{* * *} \\
(0.448) \\
\end{array}$ \\
\hline $\mathrm{R}^{2}$ & & & 27.2 & 19.3 & 25.1 & 13.1 \\
\hline
\end{tabular}

${ }^{*} \mathrm{p}<0.1 ;{ }^{* *} \mathrm{p}<0.05$; $^{* *} \mathrm{p}<0.01$.

As shown, depending on the proposed model, the $\mathrm{R}^{2}$ values vary between 13.1 and 27.3. These values are similar to or even higher than those obtained in the papers by Surroca and Santamaría (2007) on business cooperation, or those of Diéguez-Soto et al. (2016) and LópezCózar-Navarro et al. (2017) regarding FBs.

Concerning the relationship between family character (FAM) and cooperation, the results obtained confirm that hypothesis $\mathrm{H}_{1}$ can be partially accepted. According to these results, family character is positively related to vertical collaboration, both with suppliers and with customers $\left(\beta_{\mathrm{FAM}}=1.018^{* * *} ; \beta_{\mathrm{FAM}}=0.702^{* *}\right)$, which is in line with Pittino et al. (2013), De Massis et al. (2015), and Broekaert et al. (2016); however, this is not the case for horizontal or institutional cooperation, since the results do not appear to be significant. This may be because FBs often do not want to cooperate with or collaborate with partners that are not in the family group, explaining the difference with horizontal and institutional cooperation. This result is in line with Pittino and Visintin (2011), Franco and Haase (2012), Nieto et al. (2015), and Pongelli et al. (2016). These works suggest that FBs are less likely to develop inter-firm cooperation than non-family businesses. This discrepancy in the previous literature can be explained because the relationships with the different partners were not considered separately. The present research, as with that of Alberti et al. (2014) and López-Cózar et al. (2017), confirms different results depending on the nature of the partner.

Table 7 illustrates the results of the model with interactions (hypotheses $\mathrm{H}_{2}, \mathrm{H}_{3}$, and $\mathrm{H}_{4}$ ). 
Table 7

Binary Logistic Regression: Model results with interactions

\begin{tabular}{|c|c|c|c|c|c|c|}
\hline \multirow{2}{*}{$\begin{array}{l}\text { Modelo } \\
\text { General }\end{array}$} & \multicolumn{6}{|c|}{$\left(C_{-} i\right)=\beta_{0}+\beta_{1} F A M_{i}+\beta_{2} R E L A C_{i}+\beta_{3} I P R O C_{i}+\beta_{4} I P R O D_{i}+\beta_{5} Q U A_{i}+\beta_{6} G E O_{i t}+\beta_{A} A G E_{i}+\beta_{8} S I Z E_{i}+\varepsilon_{i}$} \\
\hline & \multirow{3}{*}{$H_{\mathrm{i}}$} & \multirow{3}{*}{$\begin{array}{l}\text { Expected } \\
\text { Directions }\end{array}$} & Model $_{5}$ & Model $_{6}$ & Model $_{7}$ & Model $_{8}$ \\
\hline \multirow{2}{*}{ Variables } & & & C_SUPP & C_CLI & C_UNI $_{i}$ & C_COM \\
\hline & & & Coef. (S.E) & Coef. (S.E) & Coef. (S.E) & Coef. (S.E) \\
\hline Const. & & & $\begin{array}{c}-10.922^{* * *} \\
(1.911)\end{array}$ & $\begin{array}{c}-10.205^{* * *} \\
(1.942)\end{array}$ & $\begin{array}{c}-10.793^{* * *} \\
(1.742)\end{array}$ & $\begin{array}{c}-34.327 \\
(3586.24)\end{array}$ \\
\hline FAM & & & $\begin{array}{l}1.244^{*} \\
(0.663)\end{array}$ & $\begin{array}{c}0.694 \\
(0.676)\end{array}$ & $\begin{array}{c}0.220 \\
(0.501)\end{array}$ & $\begin{array}{c}18.484 \\
(3583.244)\end{array}$ \\
\hline RELAC & & & $\begin{array}{c}-1.542^{* * *} \\
(0.538)\end{array}$ & $\begin{array}{l}-0.698 \\
(0.538)\end{array}$ & $\begin{array}{c}-1.152^{* *} \\
(0.536)\end{array}$ & $\begin{array}{c}-1.929^{* *} \\
(0.853)\end{array}$ \\
\hline IPROC & & & $\begin{array}{c}0.028 \\
(0.039)\end{array}$ & $\begin{array}{l}-0.024 \\
(0.038)\end{array}$ & $\begin{array}{c}0.052 \\
(0.037)\end{array}$ & $\begin{array}{l}-0.288 \\
(0.382)\end{array}$ \\
\hline IPROD & & & $\begin{array}{l}-0.005 \\
(0.042)\end{array}$ & $\begin{array}{c}0.014 \\
(0.038)\end{array}$ & $\begin{array}{c}0.003 \\
(0.036)\end{array}$ & $\begin{array}{c}0.107^{* *} \\
(0.042)\end{array}$ \\
\hline QUA & & & $\begin{array}{l}1.312^{* *} \\
(0.553)\end{array}$ & $\begin{array}{l}1.099^{* *} \\
(0.549)\end{array}$ & $\begin{array}{c}0.167 \\
(0.414)\end{array}$ & $\begin{array}{c}18.434 \\
(3583.244)\end{array}$ \\
\hline GEO & & & $\begin{array}{c}0.422^{* * *} \\
(0.148)\end{array}$ & $\begin{array}{c}0.556^{* * *} \\
(0.159)\end{array}$ & $\begin{array}{c}0.335^{* *} \\
(0.133)\end{array}$ & $\begin{array}{c}0.285 \\
(0.320)\end{array}$ \\
\hline AGE & & & $\begin{array}{l}-0.003 \\
(0.007) \\
\end{array}$ & $\begin{array}{c}0.011^{*} \\
(0.007)\end{array}$ & $\begin{array}{c}0.004 \\
(0.006)\end{array}$ & $\begin{array}{l}-0.009 \\
(0.012)\end{array}$ \\
\hline SIZE & & & $\begin{array}{c}1.053^{* * *} \\
(0.228)\end{array}$ & $\begin{array}{c}0.689^{* * *} \\
(0.221)\end{array}$ & $\begin{array}{c}1.201^{* * *} \\
(0.213)\end{array}$ & $\begin{array}{c}1.685^{* * *} \\
(0.487)\end{array}$ \\
\hline I_IPROC_FAM & & + & $\begin{array}{l}-0.046 \\
(0.071)\end{array}$ & $\begin{array}{l}-0.055 \\
(0.087)\end{array}$ & $\begin{array}{l}-0.023 \\
(0.067)\end{array}$ & $\begin{array}{c}0.024 \\
(0.514)\end{array}$ \\
\hline I_IPROD_FAM & $H_{2}$ & + & $\begin{array}{c}0.037 \\
(0.123)\end{array}$ & $\begin{array}{c}0.081 \\
(0.121)\end{array}$ & $\begin{array}{l}-0.045 \\
(0.117)\end{array}$ & $\begin{array}{l}0.311^{*} \\
(0.188)\end{array}$ \\
\hline I_QUA_FAM & $H_{3}$ & + & $\begin{array}{l}-0.272 \\
(0.747)\end{array}$ & $\begin{array}{l}-0.076 \\
(0.774)\end{array}$ & $\begin{array}{l}-0.177 \\
(0.636)\end{array}$ & $\begin{array}{c}-16.806 \\
(3583.244)\end{array}$ \\
\hline I_RELAC_FAM & $H_{4}$ & + & $\begin{array}{l}-0.018 \\
(0.907)\end{array}$ & $\begin{array}{c}0.365 \\
(0.880)\end{array}$ & $\begin{array}{l}-0.287 \\
(0.887)\end{array}$ & $\begin{array}{l}-2.151 \\
(1.539)\end{array}$ \\
\hline $\mathrm{R}^{2}$ & & & 27.3 & 19.8 & 25.6 & 15 \\
\hline
\end{tabular}

${ }^{*} \mathrm{p}<0.1{ }^{* *} \mathrm{p}<0.05$; $^{* *} \mathrm{p}<0.01$.

Only empirical evidence of the relationship between cooperation with competitors and FBs that innovate in products was found, so hypothesis $\mathrm{H}_{2}$ cannot be accepted. Similarly, the results obtained do not explain the relationship between cooperation and FBs that have implemented quality controls, so hypothesis $\mathrm{H}_{3}$ cannot be accepted. Finally, hypothesis $\mathrm{H}_{4}$ cannot be accepted either, since no empirical evidence was found linking business cooperation with FBs that improve the management of external relations.
Because of the non-existence in these models of significant relationships, a multicollinearity analysis was performed, which produced VIF coefficients of less than 4 in all cases, so it cannot be concluded that multicollinearity is the reason. This evidence confirms that the influence of a company's family character on cooperation, while significant different from in non-family businesses, is not due to the variables analyzed in this research, but to others. However, it is true that the use of dichotomous variables may affect these 
results. This analysis is developed in the following conclusions section.

\section{Conclusions}

This study analyzed the relationship between inter-firm cooperation and innovation, quality, and the management of external relations; distinguishing between vertical, horizontal, and institutional cooperation. Based on the study of 1,848 companies, the results obtained confirm a positive relationship between horizontal cooperation and product innovation; between vertical cooperation and the implementation of quality controls; as well as a significant relationship between cooperation in all its forms and the improvement of the management of external relations. In the case of the $\mathrm{FBs}$, the empirical evidence corroborates the existence of a relationship between vertical cooperation and family character.

Our paper makes several contributions to the literature on business cooperation and on FB inter-firm cooperation. First, by studying the cooperation and certain characteristics of the company, we empirically verified the existence of a significant correlation. While the relationship with innovation is widely studied, this is not the case with the other two variables analyzed. Our analysis allowed us to demonstrate the importance of implementing internal quality management and continuous improvement systems.

Secondly, in the case of FBs, previous studies show different results in terms of the tendency to cooperate in these companies, so this research helps to clarify this issue by having considered the different types of partners separately. Indeed, except for some studies (Classen et al., 2012; Alberti et al., 2014; LópezCózar-Navarro et al., 2017), our paper is one of the first to provide empirical evidence regarding the influence of the nature of the relationship with the chosen partner. As is the general case for other companies, the results show that the chosen partner has a different effect on the relationships analyzed. Thus, a positive connection was found between family character and cooperation with customers and suppliers, but not in the case of cooperation with competitors or universities. This positive relationship can be influenced by the organizational culture of the $\mathrm{FB}$, based on beliefs and family values, since the commitment and trust of the people who are part of the organization, as well as the knowledge, experience, and skills of the family entrepreneur, exert a positive influence in fostering cooperation with third parties.

Finally, linking cooperation with different aspects of the firm allows for progress in the knowledge on a topic that is not frequently addressed in the literature and in which the previous research shows discrepancies (Feranita et al., 2017; Brinkerink, 2018). The article also contributes to the literature by distinguishing between product innovation and process innovation, as there is a different relationship for the specific case of product innovation; this corroborates the existence of a relationship between horizontal cooperation and FBs that innovate in products.

The results presented have interesting implications for FB executives, as they may help them better understand the importance of business cooperation, as well as the keys to building strong relationships with third parties, which may allow them to achieve better results. In addition, they should be aware of the different implications of the nature of the chosen partner when making cooperation decisions. It is particularly noteworthy that a significant relationship exists with vertical cooperation. By establishing a strong relationship with customers, the company can find in them an important source of information to better define its commercial offer, incorporating in the products the characteristics and attributes demanded by them. This collaboration facilitates the identification of new market opportunities and improves the strategic decision-making process. On the other hand, the relationship with suppliers allows the company to improve the design and quality of its products, optimize the 
management of stocks, adjust production times and, in general, reduce costs.

It should also be highlighted that there is no significant relationship between family character and horizontal and institutional collaboration. This seems to confirm some distrust and reluctance to share resources and information with direct competitors, as well as distancing from universities and research centers. Moreover, we cannot confirm the existence of a relationship between cooperation and FBs that innovate in processes, that are committed to quality, and that manage the improvement of external relations. Thus, differences between family and non-family businesses in cooperation may be caused by other unanalyzed variables.

As noted, FBs tend to retain more control of their activity to ensure that the family vision and values are maintained, to protect the family's assets, and to ensure the movement of the company to the next generation. However, cooperation allows each partner to maintain its organizational structure and corporate culture, so it can be a particularly appropriate strategy for FBs. On the other hand, those responsible for companies and institutions wishing to cooperate with FBs should consider their peculiarities and emotional aspects when establishing cooperation agreements.

Three main limitations can be noted: firstly, the national character of the sample, since the study was carried out using only Spanish companies; secondly, the time horizon of the analysis, as it is limited to a single year; and thirdly, the fact that it is a study based solely on the manufacturing sector. In addition, the explanatory result of the proposed models should be detailed, consequently improving their $\mathrm{R}^{2}$. Taking these limitations into account, future lines of research are proposed. It would be interesting to complement this work by carrying out a more preliminary analysis based on panel data, in which the time horizon is broadened, introducing new quantitative variables, reducing existing dichotomous ones, improving coding, and using data from other countries and other sectors, in order to carry out a global study and be able to compare the different results.

\section{Note}

1 Information available at: https://www.fundacionsepi.es/ investigacion/esee/svariables/indice.asp.

\section{References}

Alberti, F. G., Ferrario, S., Papa, F., \& Pizzurno, E. (2014). Search breadth, open innovation and family firms: evidences in Italian mid-high tech SMEs. International Journal of Technology Intelligence and Planning, 10(1), 29-48.

Adler, P. S., \& Kwon, S. W. (2002). Social capital: Prospects for a new concept. Academy of Management Review, 27(1), 17-40.

Ardito, L., Messeni Petruzzelli, A., Pascucci, F., \& Peruffo, E. (2019). Inter-firm R\&D collaborations and green innovation value: The role of family firms' involvement and the moderating effects of proximity dimensions. Business Strategy and the Environment, 28(1), 185-197.

Bigliardi, B., \& Galati, F. (2018). Family firms and collaborative innovation: present debates and future research. European Journal of Innovation Management, 21(2), 334-358.

Belderbos, R., Carree, M., Diederen, B., \& Lokshin, B. (2004). Heterogeneity in R\&D cooperation strategies. International Journal of Industrial Organization, 22(8-9), 1237-1263.

Benito-Hernández, S., Priede-Bergamini, T., \& López-Cózar-Navarro, C. (2014). Factors determining exportation and internationalization in family businesses: The importance of debt. South African Journal of Business Management, 45(1), 13-25.

Bingham, J. B., Dyer, W. G., Smith, I., \& Adams, G. L. (2011). A stakeholder identity orientation approach to corporate social performance in 
family firms. Journal of Business Ethics, 99(4), 565-585.

Brinkerink, J. (2018). Broad search, deep search, and the absorptive capacity performance of family and nonfamily firm R\&D. Family Business Review, 31(3), 295-317.

Broekaert, W., Andries, P., \& Debackere, K. (2016). Innovation processes in family firms: the relevance of organizational flexibility. Small Business Economics, 47(3), 771-785.

Cabrera-Suarez, M. K., Déniz, M. C., \& Martín, J. (2011). Familiness and market orientation: A stakeholder approach. Journal of Family Business Strategy, 2(1), 34-42.

Camisón, C., Boronat, M., Villar, A., \& Puig, A. (2009). Sistemas de gestión de la calidad y desempeño: Importancia de las prácticas de gestión del conocimiento y de I+ D. Revista Europea de Dirección y Economía de la Empresa, 18(1), 123-134.

Cassiman, B., \& Veugelers, R. (2002). R\&D cooperation and spillovers: some empirical evidence from Belgium. American Economic Review, 92(4), 1169-1184.

Cho, H. J., \& Pucik, V. (2005). Relationship between innovativeness, quality, growth, profitability, and market value. Strategic Management Journal, 26(6), 555-575.

Chriman, J. J., Chua, J. H., Massis, A. de, Minola, T., \& Vismara, S. (2016). Management processes and strategy execution in family firms: From "what" to "how". Small Business Economics, 47(3), 719-734.

Chrisman, J. J., \& Patel, P. C. (2012). Variations in $\mathrm{R} \& \mathrm{D}$ investments of family and nonfamily firms: Behavioral agency and myopic loss aversion perspectives. Academy of Management Journal, 55(4), 976-997.
Chun, H., \& Mun, S.-B. (2012). Determinants of R\&D cooperation in small and medium-sized enterprises. Small Business Economics, 39(2), 419-436.

Chung, S. A., \& Kim, G. M. (2003). Performance effects of partnership between manufacturers and suppliers for new product development: the supplier's standpoint. Research Policy, 32(4), 587-603.

Classen, N., Gils, A. van, Bammens, Y., \& Carree, M. (2012). Accessing resources from innovation partners: The search breadth of family SMEs. Journal of Small Business Management, 50(2), 191-215.

Classen, N., Carree, M., Gils, A. van, \& Peters, B. (2014). Innovation in family and non-family SMEs: an exploratory analysis. Small Business Economics, 42(3), 595-609.

Cooper, M. J., Upton, N., \& Seaman, S. (2005). Customer relationship management: A comparative analysis of family and nonfamily business practices. Journal of Small Business Management, 43(3), 242-256.

Danes, S. M., Loy, J. T. C., \& Stafford, K. (2008). Business planning practices of family-owned firms within a quality framework. Journal of Small Business Management, 46(3), 395-421.

Das, T. K., \& Teng, B. S. (2000). A resourcebased theory of strategic alliances. Journal of Management, 26(1), 31-61.

Diéguez-Soto, J., Manzaneque, M., \& RojoRamírez, A. A. (2016). Technological innovation inputs, outputs, and performance: The moderating role of family involvement in management. Family Business Review, 29(3), 327-346.

Duran, P., Kammerlander, N., Essen, M. van, \& Zellweger, T. (2016). Doing more with less: Innovation input and output in family firms. Academy of Management Journal, 59(4), 12241264. 
Ellington, E. P., Jones, R. T., \& Deane, R. (1996). TQM adoption practices in the family-owned business. Family Business Review, 9(1), 5-14.

Faems, D., Looy, B. van, \& Debackere, K. (2005). Interorganizational collaboration and innovation: Toward a portfolio approach*. Journal of Product Innovation Management, 22(3), 238-250.

Feranita, F., Kotlar, J., \& Massis, A. de (2017). Collaborative innovation in family firms: Past research, current debates and agenda for future research. Journal of Family Business Strategy, 8, 137-156.

Fernández, M., \& Martín, J. (2006). La confianza y el compromiso como factores clave del éxito de las relaciones comerciales: Una aplicación empírica en el sistema de franquicia. Revista Europea de Dirección y Economia de la Empresa, 15(1), 77-100.

Fink, M., \& Kessler, A. (2010). Cooperation, trust and performance-empirical results from three countries. British Journal of Management, 21(2), 469-483.

Franco, M., \& Haase, H. (2012). A comparative study of cooperative relationships in family and non-family businesses. African Journal of Business Management, 6(44), 10873-10887.

Garcés-Galdeano, L., García-Olaverri, C., GarcíaOlaverri, C., \& Huerta, E. (2016). Management capability and performance in Spanish family firms. Academia, Revista Latinoamericana de Administración, 29(3), 303-325.

Graves, C., \& Thomas, J. (2008). Determinants of the internationalization pathways of family firms: an examination on family business. Family Business Review, 21(2), 151-167.

Grütter, A., Field, J., \& Faull, N. (2002). Work team performance over time: three case studies of South African manufacturers. Journal of Operations Management, 20(5), 641-657.
Hadjielias, E., \& Poutziouris, P. (2015). On the conditions for the cooperative relations between family businesses: the role of trust. International Journal of Entrepreneurial Behavior \& Research, 21(6), 867-897.

Hagedoorn, J. (1993). Understanding the rationale of strategic technology partnering: Interorganizational modes of cooperation and sectoral differences. Strategic Management Journal, 14(5), 371-385.

Härtel, C. E., Bozer, G., \& Levin, L. (2010). Family business leadership transition: How an adaptation of executive coaching may help. Journal of Management \& Organization, 15(3), 378-391.

Hoang, H., \& Rothaermel, F. (2005). The effect of general and partner-specific alliance experience on joint R\&D project performance. Academy of Management Journal, 48(2), 332-345.

Ibrahim, N. A., Angelidis, J. P., \& Parsa, F. (2008). Strategic management of family businesses: Current findings and directions for future research. International Journal of Management, 25(1), 95-110.

Jesus, M., Nieto, \& Santamaría, L. (2007). The importance of diverse collaborative networks for the novelty of product innovation. Technovation, 27(6), 367-377.

Jesus, M., Nieto, Santamaría, L., \& Fernández, Z. (2015). Understanding the innovation behavior of family firms. Journal of Small Business Management, 53(2), 382-399.

Jones, J., \& Corral de Zubielqui, G. C. (2017). Doing well by doing good: A study of universityindustry interactions, innovationess and firm performance in sustainability-oriented Australian SMEs. Technological Forecasting and Social Change, 123, 262-270.

Kaynak, H. (2003). The relationship between total quality management practices and their 
effects on firm performance. Journal of Operations Management, 21(4), 405-435.

Kellermanns, F. W., Eddleston, K. A., Sarathy, R., \& Murphy, F. (2012). Innovativeness in family firms: A family influence perspective. Small Business Economics, 38(1), 85-101.

Lakhal, L., Pasin, F., \& Limam, M. (2006). Quality management practices and their impact on performance. International Journal of Quality \& Reliability Management, 23(6), 625-646.

Larentis, F., Antonello, C. S., \& Slongo, L. A. (2018). Organizational culture and relationship marketing: An interorganizational perspective. Revista Brasileira de Gestão de Negócios, 20(1), 37-56.

López-Cózar-Navarro, C., Benito-Hernández, S., \& Platero-Jaime, M. (2017). The influence of cooperative relations on geographical expansion and diversification strategies in family firms. International Business Review, 26(4), 764-776.

Marchi, V. de (2012). Environmental innovation and R\&D cooperation: Empirical evidence from Spanish manufacturing firms. Research Policy, 41(3), 614-623.

Martínez-Román, J. A., Gamero, J., \& Tamayo, J. A. (2011). Analysis of innovation in SMEs using an innovative capability-based non-linear model: A study in the province of Seville (Spain). Technovation, 31(9), 459-475.

Mazzelli, A., Kotlar, J., \& Massis, A. (2018). Blending in while standing out: Selective conformity and new product introduction in family firms. Entrepreneurship Theory and Practice, 42(2), 206-230.

Massis, A. de, Frattini, F., \& Lichtenthaler, U. (2012a). Research on technological innovation in family firms: Present debates and future directions. Family Business Review, 26(1), 10-31.
Massis, A. de, Sharma, P., Chua, J., \& Chrisman, J. (2012b). Family business studies: An annotated bibliography. Northhampton, MA: Edward Elgar.

Massis, A. de, Frattini, F., Pizzurno, E., \& Cassia, L. (2015). Product innovation in family versus nonfamily firms: An exploratory analysis. Journal of Small Business Management, 53(1), 1-36.

McAdam, R., Armstrong, G., \& Kelly, B. (1998). Investigation of the relationship between total quality and innovation: A research study involving small organizations. European Journal of Innovation Management, 1(3), 139-147.

Meroño-Cerdán, Á. L., \& López-Nicolás, C. (2017). Women in management: Are family firms somehow special? Journal of Management \& Organization, 23(2), 224-240.

Miotti, L., \& Sachwald, F. (2003). Co-operative R\&D: Why and with whom? An integrated framework of analysis. Research Policy, 32(8), 1481-1499.

Naldi, L., Nordqvist, M., Sjoberg, K., \& Wiklund, J. (2007). Entrepreneurial orientation, risk taking, and performance in family firms. Family Business Review, 20(1), 33-47.

Nahapiet, J., \& Ghoshal, S. (1998). Social capital, intellectual capital, and the organizational advantage. Academy of Management Review, 23(2), 242-266.

Niemelä, T. (2004). Interfirm cooperation capability in the context of networking family firms: The role of power. Family Business Review, 17(4), 319-330.

Olander, H., Hurmelinna-Laukkanen, P., \& Mähönen, J. (2009). What's small size got to do with it? Protection of intellectual assets in SMEs. International Journal of Innovation Management, 13(3), 349-370.

Padilla-Meléndez, A., Dieguez-Soto, J., \& Garrido-Moreno, A. (2015). Empirical research 
on Innovation in Family Business: literature review and proposal of an integrative framework. Revista Brasileira de Gestão de Negócios, 17(56), 1064-1089.

Pittino, D., \& Visintin, F. (2011). The propensity toward inter-organizational cooperation in smalland medium-sized family businesses. Journal of Family Business Strategy, 2(2), 57-68.

Pittino, D., Visintin, F., Bau', M., \& Mazzurana, P. (2013). Collaborative technology strategies and innovation in family firms. International Journal of Entrepreneurship and Innovation Management, $17(1-3), 8-27$.

Pongelli, C., Caroli, M. G., \& Cucculelli, M. (2016). Family business going abroad: The effect of family ownership on foreign market entry mode decisions. Small Business Economics, 47(3), 787-801.

Roessl, D. (2005). Family businesses and interfirm cooperation. Family Business Review, 18(3), 203214.

Rogers, M. (2004). Networks, firm size and innovation. Small Business Economics, 22(2), 141-153.

Sanchez-Famoso, V. (2015). Family firm and social capital: A brief literature review. Mediterranean Journal of Social Sciences, 6(5), 67.

Sanchez-Famoso, V., Akhter, N., Iturralde, T., Chirico, F., \& Maseda, A. (2015). Is non-family social capital also (or especially) important for family firm performance? Human Relations, 68(11), 1713-1743.

Sanchez-Famoso, V., Maseda, A., \& Iturralde, T. (2017). Family involvement in top management team: Impact on relationships between internal social capital and innovation. Journal of Management \& Organization, 23(1), 136-162.
Santamaría, L., \& Surroca, J. (2011). Matching the goals and impacts of R\&D collaboration. European Management Review, 8(2), 95-109.

Sarkar, M. B., Echambadi, R., Cavusgil, S. T., \& Aulakh, P. S. (2001). The influence of complementarity, compatibility, and relationship capital on alliance performance. Journal of the Academy of Marketing Science, 29(4), 358-373.

Serrano-Bedia, A., López-Fernández, C., \& García-Piqueres, G. (2010). Decision of institutional cooperation on R\&D. Determinants and sectoral differences. European Journal of Innovation Management, 13(4), 439-465.

Soosay, C. A., Hyland, P. W., \& Ferrer, M. (2008). Supply chain collaboration: Capabilities for continuous innovation. Supply Chain Management: An International Journal, 13(2), 160-169.

Suárez-Barraza, M. F. (2013). Process Innovation in Local Governments: An empirical study of its continuous improvement efforts. Revista Brasileira de Gestão de Negócios, 15(47), 204-220.

Suárez-Barraza, M. F., Ramis-Pujol, J., \& Sándoval-Arzaga, F. (2011). Finding kaizen approach in small Mexican family businesses: an exploratory study. Journal of Family Business Management, 1(2), 107-129.

Surroca, J., \& Santamaría, L. (2007). La cooperación tecnológica como determinante de los resultados empresariales. BRQ Business Research Quarterly, 10(33), 31-62.

Tamayo, J. A., Romero, J. E., Gamero, J., \& Martínez-Román, J. A. (2015). Do innovation and cooperation influence SMEs' competitiveness? Evidence from the Andalusian metal-mechanic sector. Innovar, 25(55), 101-115.

Tambunan, T. (2005). Promoting small and medium enterprises with a clustering approach: A policy experience from Indonesia. Journal of Small Business Management, 43(2), 138-154. 
Tether, B. S. (2002). Who cooperates for innovation, and why. An empirical analysis. Research Policy, 31(6), 947-967.

Terziovski, M., \& Sohal, A. S. (2000). The adoption of continuous improvement and innovation strategies in Australian manufacturing firms. Technovation, 20(10), 539-550.

Tuffa Birru, W. (2011). Horizontal interfirm cooperation in Ethiopian small and medium enterprises: Evidence from leather shoe manufacturing firms in Addis Ababa. Journal of Small Business and Enterprise Development, 18(4), 806-820.

Weismeier-Sammer, D. (2014). The role of familiness for family business innovativeness. International Journal of Entrepreneurial Venturing, 6(2), 101-117.
Werner, A., Schröder, C., \& Chlosta, S. (2018). Driving factors of innovation in family and nonfamily SMEs. Small Business Economics, 50(1), 201-218.

Zahra, S. A. (2005). Entrepreneurial risk taking in family firms. Family Business Review, 18(1), 23-40.

Zahra, S. A., Hayton, J. C., \& Salvato, C. (2004). Entrepreneurship in family vs. non-family firms: A resource-based analysis of the effect of organizational culture. Entrepreneurship Theory and Practice, 28(4), 363-381.

Zeng, S. X., Xieb, X. M., \& Tam, C. M. (2010). Relationship between cooperation networks and innovation performance of SMEs. Technovation, 30(3), 181-194 


\section{Authors:}

1. Cristina López-Cózar-Navarro, PhD, Polytechnic University of Madrid, Agrarian Economics, Statistics and Business Management, Madrid, Spain.

E-mail: cristina.lopezcozar@upm.es

ORCID

(iD) 0000-0002-2788-9896

2. Tiziana Priede-Bergamini, PhD, European University of Madrid, Economy and Business, Madrid, Spain. E-mail: tiziana.priede@universidadeuropea.es

ORCID

(iD) 0000-0002-4622-3328

3. Sonia Benito-Hernández, PhD, Polytechnic University of Madrid, Agrarian Economics, Statistics and Business Management, Madrid, Spain. E-mail: sonia.benito@upm.es

ORCID

(iD) 0000-0001-7422-3897

\section{Contribution of each author}

\begin{tabular}{lccc}
\hline Contribution & $\begin{array}{c}\text { Cristina } \\
\text { Navarro }\end{array}$ & $\begin{array}{c}\text { Tiziana Priede- } \\
\text { Bergamini }\end{array}$ & $\begin{array}{c}\text { Sonia Benito- } \\
\text { Hernández }\end{array}$ \\
\hline $\begin{array}{l}\text { 1. Definition of research problem } \\
\text { 2. Development of hypotheses or research questions (empirical studies) }\end{array}$ & $\sqrt{ }$ & $\sqrt{ }$ & $\sqrt{ }$ \\
3. Development of theoretical propositions (theoretical Work) & $\sqrt{ }$ & $\sqrt{ }$ \\
4. Theoretical foundation/ Literature review & $\sqrt{ }$ & $\sqrt{ }$ \\
5. Definition of methodological procedures & & $\sqrt{ }$ \\
6. Data collection & & $\sqrt{ }$ \\
7. Statistical analysis & & $\sqrt{ }$ \\
8. Analysis and interpretation of data & $\sqrt{ }$ \\
9. Critical revision of the manuscript & & $\sqrt{ }$ \\
10. Manuscript Writing & & $\sqrt{ }$ \\
11. Other (please specify which) & & $\sqrt{ }$ \\
\end{tabular}

